\title{
Boundary Layer Experiment 1996 (BLX96)
}

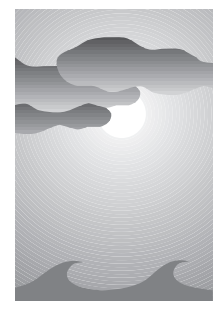

\author{
Roland Stull, Edi Santoso, Larry Berg, and Joshua Hacker \\ Atmospheric Science Programme, Department of Geography, \\ The University of British Columbia, Vancouver, British Columbia, Canada
}

\begin{abstract}
The University of Wyoming King Air aircraft was the primary instrument platform for turbulence measurements in the bottom half of the convective boundary layer during 15 July-13 August 1996. A total of 12 successful research flights were made, each of about 4.5-h duration. Crosswind (east-west) flight patterns were flown in Oklahoma and Kansas over three sites of different land use: forest, pasture, and crops.

Measurements of mean values, turbulent deviations, and turbulent fluxes of temperature, moisture, and momentum were made to test theories of convective transport, the radix layer, and cumulus potential. Additional portions of each flight included slant soundings and near-surface horizontal flights in order to determine mixed layer (ML) scaling variables such as ML depth $z_{i}$, Deardorff velocity $w_{*}$, and buoyancy velocity $w_{B}$. While the ML was shallower and the ground wetter than anticipated based on climatology, a high-quality dataset was obtained.
\end{abstract}

\section{Introduction}

During 15 July-13 August 1996, The University of British Columbia (UBC) conducted a boundary layer field experiment (BLX96) in Oklahoma and Kansas. BLX96 consisted of three subexperiments within the daytime convective mixed layer (ML):

- Convective transport theory (CTT),

- Radix layer (RxL), and

- Boundary-layer cumulus (BLCu).

The University of Wyoming (UW) King Air aircraft (N2UW) was the primary instrument platform for this experiment, based at Ponca City, Oklahoma $\left(36^{\circ} 44.0^{\prime} \mathrm{N}, 97^{\circ} 06.0^{\prime} \mathrm{W}\right)$.

BLX96 coincided with a routine U.S. Department of Energy (DOE) Atmospheric Radiation Measurement (ARM) Program intensive operation

Corresponding author address: Roland B. Stull, Atmospheric Science Programme, Dept. of Geography, UBC, 1984 West Mall, Vancouver, BC V6T 1Z2, Canada.

E-mail: rstull@geog.ubc.ca

In final form 12 December 1996.

(C)1997 American Meteorological Society period, conducted from 15 July to 4 August 1996 at the Cloud and Radiation Testbed (CART) region in the southern Great Plains (SGP). The central facility $\left(36.605^{\circ} \mathrm{N}, 97.485^{\circ} \mathrm{W}\right.$, elevation $\left.318 \mathrm{~m}\right)$ of CART is near Lamont, Oklahoma, although the full $143000-\mathrm{km}^{2}$ CART region spans parts of Kansas and Oklahoma. Collaborators from Argonne National Laboratory (ANL) and the National Center for Atmospheric Research (NCAR) brought ground-based remote sensors into the CART region, near the BLX96 flight tracks.

\section{a. Convective transport theory}

During free convective conditions of light winds and statically unstable air, vertical transport is caused primarily by thermals. The convective transport velocity (Stull 1994) $w_{B}=\left(\beta z_{\mathrm{i}} \Delta \theta_{\mathrm{v}}\right)^{1 / 2}$ is a measure of this transport rate, where $\beta=g / T_{\mathrm{v}}$ is the buoyancy parameter, $g$ is gravitational acceleration, $T_{\mathrm{v}}$ is virtual absolute temperature in the mid-ML, $z_{\mathrm{i}}$ is the average ML depth, and $\Delta \theta_{\mathrm{v}}$ is the virtual potential temperature difference between the surface skin and the mid-ML. Surface fluxes under these conditions are expected to be proportional to this buoyancy velocity times the difference in mean condition between the surface skin and the mid-ML; for example, $\overline{\mathrm{w}^{\prime} \boldsymbol{\theta}^{\prime}}{ }_{s}$ 
$=b_{\mathrm{H}} w_{\mathrm{B}} \Delta \theta$, where empirical constant $b_{\mathrm{H}} \approx 0.0005$, and $\Delta \theta=\theta_{\text {skin }}-\theta_{\text {midML }}$.

Convective transport theory (CTT) predicts that surface fluxes should be independent of roughness length for free convection, where free convection occurs approximately when the mixed layer Richardson number, $R^{*}=\left(w_{B} / M_{M L}\right)^{2}$, is greater than 3 , where $M_{M L}$ is mid-ML wind speed. It also suggests a diagnostic way to estimate ML depth from surface fluxes and skin-ML temperature differences. Extensions to this theory allow for nonzero mean wind. To test CTT and its empirical parameters, BLX96 included measurements of eddy-correlation fluxes over three sites with different aerodynamic roughness. A downward-looking infrared (IR) radiation thermometer on the aircraft remotely measured surface skin temperature. The aircraft also made in situ measurements of wind, temperature, and humidity in the mid-ML.

\section{b. Radix layer}

For free convection, the ML can be divided into layers identified by shapes of the mean profiles. Traditionally, the surface layer (SL) is defined as the region where 1) turbulent fluxes are roughly constant with height near the surface, 2) MoninObukhov similarity theory applies, 3) wind profiles are nearly logarithmic, and 4) mechanically generated turbulence is important. In the interior of the ML is a uniform layer (UL) where wind speed and potential temperature are approximately constant with height and where buoyantly generated turbulence dominates. However, there is often a large gap between the top of the SL and the bottom of the UL, which is also the region where only a limited amount of field data exists. Within this gap, free convection scaling can apply (Holtslag and Nieuwstadt 1986; Panofsky 1978).

A radix layer ( $\mathrm{RxL}$ ) has been identified by Santoso (1993) and Santoso and Stull (1997a, manuscript submitted to J. Atmos. Sci.) as the whole region between the surface and the base of the UL (Fig. 1). The classic SL and classic free convection scaling layer are subsets of the RxL. At the top of the RxL, the wind speed becomes tangent to UL wind speed. Typical RxL depths are on the order of 100-300 m for wind speed and 20-70 m for potential temperature. The Latin name "radix," meaning root or base, was suggested because the $\mathrm{RxL}$ is at the root of thermals.

To investigate the RxL, a vertical zig-zag flight pattern was flown to provide vertical profiles of mean wind, temperature, and humidity between altitudes of about 5 and $700 \mathrm{~m}$ above ground level (AGL). This spans the SL, the RxL, and the bottom of the UL. In addition, higher sounding legs were flown to get $z_{i}$, and near-surface level legs were flown to get eddy-correlation fluxes from which the Deardorff $\left\{w_{*}=\left[\left(g / T_{v}\right) z_{i} \overline{\mathrm{w}^{\prime} \theta_{v}}{ }_{s}\right]^{1 / 3}\right\}$ and buoyancy $\left(w_{B}\right)$ velocities could be found, where $\overline{\mathrm{w}^{\prime} \theta_{v}}$, is the vertical eddy flux of virtual potential temperature at the surface. To test dependency of the RxL to surface roughness and land use, three regions of differing land use were chosen for the flight tracks.

\section{c. Boundary layer cumulus}

Heterogeneous land surfaces cause small differences in near-surface air temperature and humidity, which modulate characteristics of rising thermals and control the formation of boundary layer cumulus (BLCu). Air parcels born over a variety of surfaces tend to rise to a range of heights, depending on their buoyancies. Buoyancy can be quantified by the virtual potential temperature $\left(\theta_{v}\right)$ difference between the parcel and the ambient $\theta_{v}$ profile. The probability of a parcel to form a cumulus cloud also depends on its individual lifting condensation level (LCL) height $\left(z_{\mathrm{LCL}}\right)$.

The joint frequency distribution (JFD) of $\theta_{v}$ versus $z_{\mathrm{LCL}}$ can be used as a predictor of BLCu (Schrieber et al. 1996). Such a JFD consists of three sectors (Fig. 2). Parcels that have a $\theta_{v}$ less than the

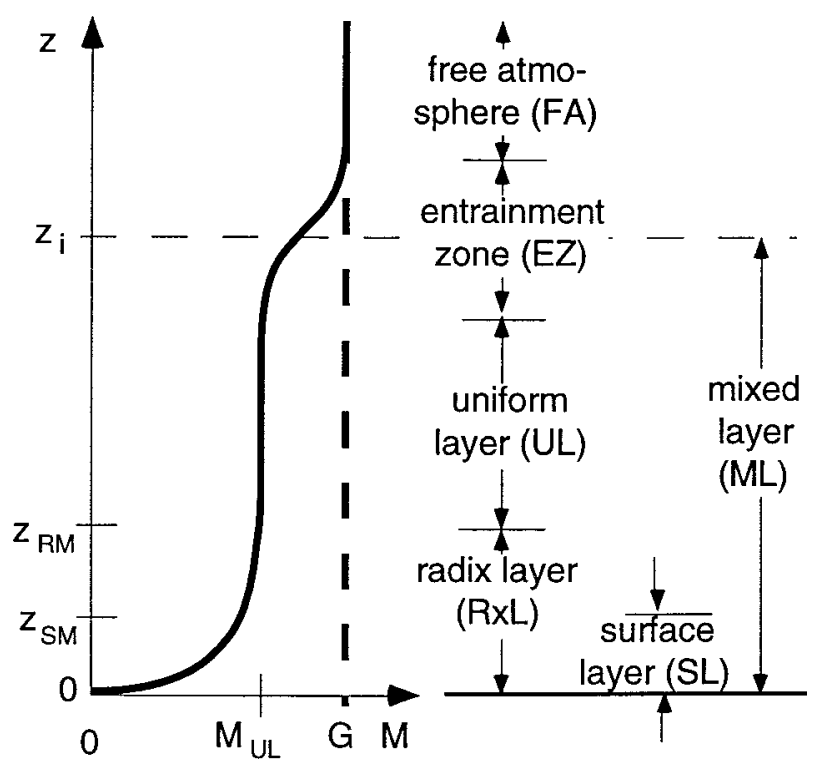

FIG. 1. Layers within the convective ML, where $\mathrm{M}$ is wind speed and $\mathrm{G}$ is geostrophic wind speed. 
environment comprise sector one; they are not buoyant and will not form BLCu. Sector two includes parcels that have $\theta_{v}$ greater than the environment; they are buoyant but will stop rising at their height of neutral buoyancy before making $\mathrm{BLCu}$. Buoyant parcels in sector three are moist enough to reach their LCLs before reaching their height of neutral buoyancy and thus will form clouds. By tracking each parcel, one can diagnose the range of cloud-base heights and cloud thickness. The portion of JFD within sector three gives fractional forced and active cloudiness (Stull 1985) associated with rising thermals.

BLX96 investigated how the JFD changes with height and land use. To investigate land use effects we flew over three different locations that were predominantly pasture, forest, and cultivated farm fields, respectively. Fast response temperature, humidity, and altitude were measured to calculate the JFDs. These JFDs were measured at five altitudes within the RxL.

\section{Site}

\section{a. Overview}

Relatively flat topography, large areas of uniform land use, frequent fair weather, numerous airports, and existing field instrumentation motivated the selection of the U.S. southern Great Plains for the field site.

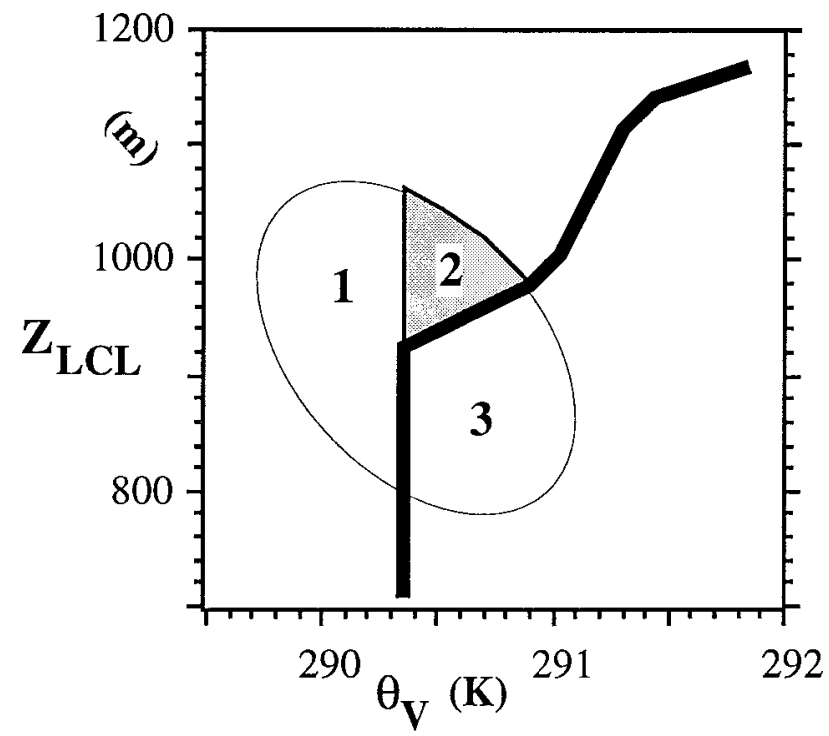

FIG. 2. Cumulus cloud triggering as a function of the ambient sounding (heavy line) and the joint frequency distribution (oval indicates JFD envelope) of LCL vs virtual potential temperature.
Major cities include Wichita, Kansas, to the north; Tulsa, Oklahoma, to the east; and Oklahoma City, Oklahoma, to the south. These cities were distant enough to cause no major alteration of the weather over the field site. The terrain elevation was roughly $300 \mathrm{~m}$ above mean sea level (MSL) and generally sloped up toward the west-northwest with a mean gradient of $1 / 900$.

\section{b. Land use under each flight track}

Figure 3 shows the locations of flight tracks in north-central Oklahoma and south-central Kansas. These east-west tracks are crosswind relative to the prevailing southerly winds. Ends of flight tracks are named after nearby villages, and the underlined name is used as a generic site identifier.

1) LAMONT

The Lamont flight track is over an area that was predominantly agricultural with a few small towns. Each of the towns covers less than $3 \mathrm{~km}^{2}$. The agricultural land was mainly nonirrigated wheat and pasture. A few of the farm fields were planted with sorghum, alfalfa, and hay. Land use ranged from

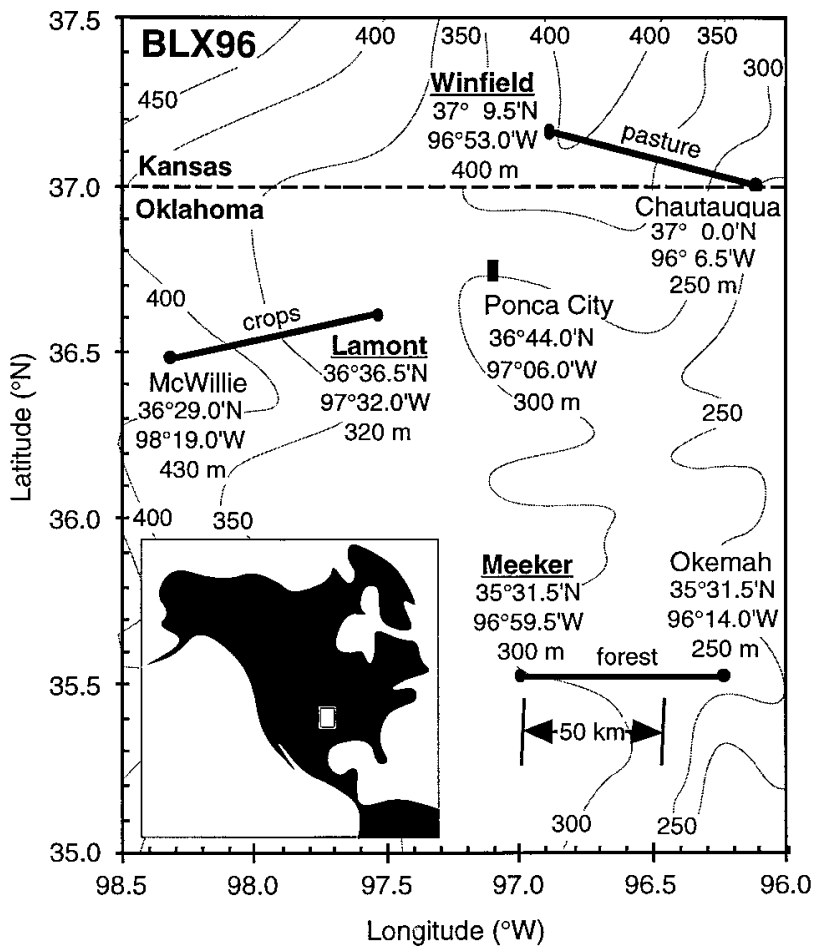

FIG. 3. Locations of flight tracks (dark lines) in north-central Oklahoma and south-central Kansas. White box in insert shows site location within North America. Smoothed elevation (thin gray) is contoured every $50 \mathrm{~m}$. 
$60 \%-80 \%$ wheat fields to $40 \%-20 \%$ pasture-other crops. Roughly $40 \%$ of the cultivated fields were recently plowed at the time of the experiment, leaving the reddish-brown soil bare. There were a small number of trees, predominantly along fence rows and drainage areas. Most of the trees were less than $10 \mathrm{~m}$ tall. The terrain under the track was rather flat but gently rising to the west, with elevations ranging from 320 to $425 \mathrm{~m}$. The eastern edge of this flight track was $3 \mathrm{~km}$ west of the ARM CART "Lamont" Central Facility site.

\section{2) WINFIELD}

The Winfield flight track was over an area of rangeland and woods. The track passed by several small towns, each less than $3 \mathrm{~km}^{2}$. There was a large quarry near the middle of the track. Tree coverage ranged from $50 \%$ to about $10 \%$, with the east end being more wooded. Pasture coverage ranged from $60 \%$ to $30 \%$. Other agricultural uses, such as hay meadows, sorghum, soy beans, alfalfa, and cotton fields covered 0\%-30\%. Most of the trees, even in the forested areas, were less than $10 \mathrm{~m}$ tall. Elevations at the west end of the track were near $400 \mathrm{~m}$, while those at the east were $250 \mathrm{~m}$. Small hills near the center of the flight track ranged from 70 to $100 \mathrm{~m}$ above local ground level.

\section{3) Meeker}

The Meeker flight track had more small rolling hills than the other tracks. The area was a mix of forest, rangeland, and pasture. This track had the densest forest and more lakes and ponds. Common trees are hackberry, cottonwood, elm, cedar, osage orange, and oak. The track passed close to several small towns, most under $3 \mathrm{~km}^{2}$. Okemah Lake (about $5 \mathrm{~km}^{2}$ ) was under the eastern end of the track. Tree coverage was $40 \%-60 \%$, cropland $10 \%-30 \%$, and pasture $40 \%-50 \%$. Trees in the area were generally under $10 \mathrm{~m}$ tall. The western end of the flight track had more cultivated fields than did the east end. Crops grown in the area included wheat, sorghum, alfalfa, cotton, and hay. The elevation at the west end of the Meeker track was about $280 \mathrm{~m}$, while the east end was near $250 \mathrm{~m}$. Hills along the flight track ranged from 40 to $60 \mathrm{~m}$ AGL.

\section{Measurements and instrumentation}

a. Measurements and procedures

Measured quantities include:

- vertical profiles of mean variables including horizontal wind components, temperature, and humidity from the surface to above the ML top;

- ML depth, $z_{i}$;

- near-surface, eddy-correlation fluxes of heat, moisture, and momentum;

- upward and downward short and longwave radiation;

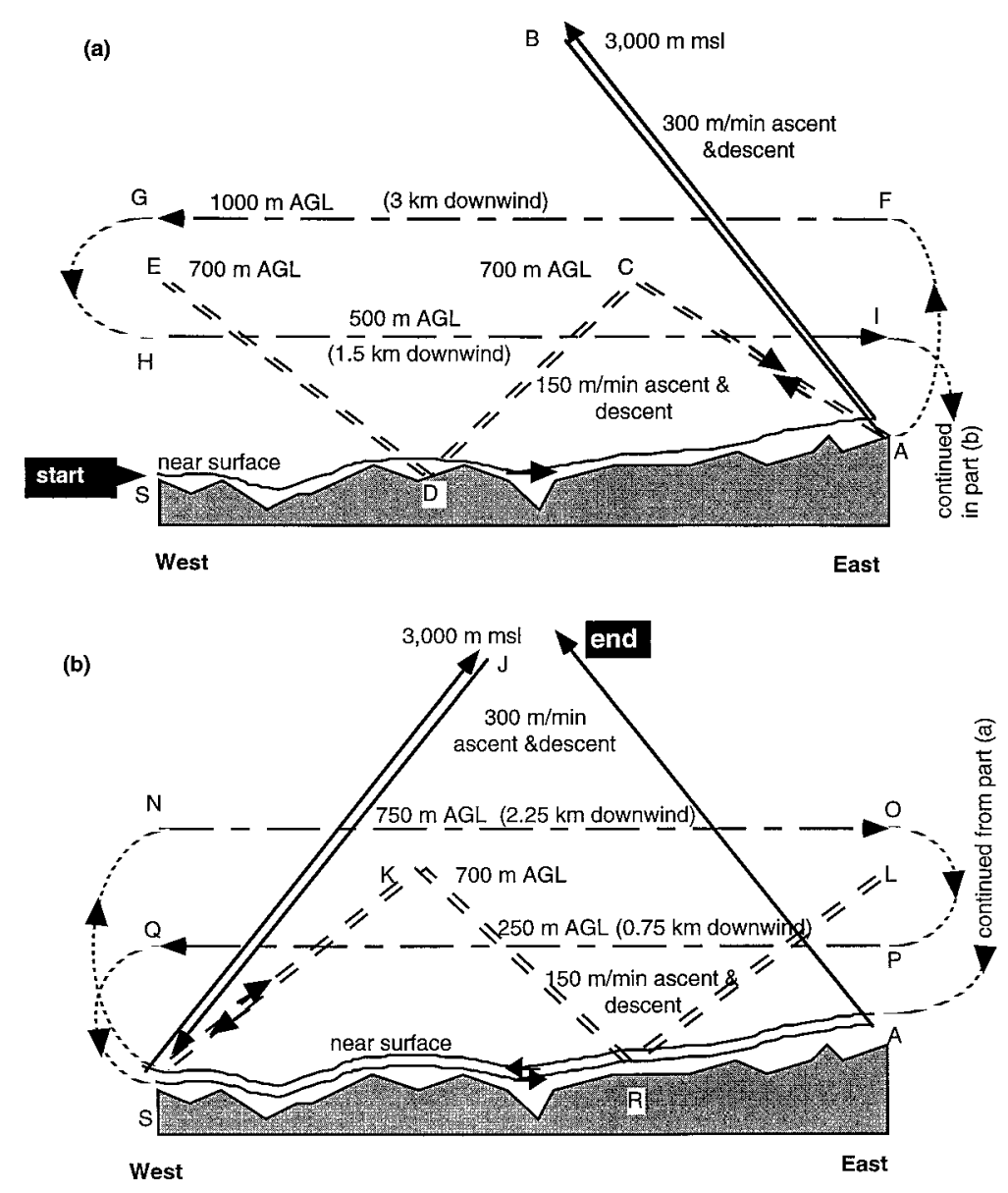

FIG. 4. Sketch of typical east-west flight pattern. Solid lines indicate measurement of ML scaling variables, dashed lines indicate radix-layer measurements, long-short dashed lines were to measure boundary-layer cumulus formation factors, and the dotted lines were turns made outside the measurement domain. Letters index key points during the flight. Sketch (b) is a continuation from (a). 
- land use imagery;

- surface radiometric skin temperature statistics;

- cumulus cloud coverage; and

- joint frequency distributions of virtual potential temperature and lifting condensation level.

A single flight pattern was designed to satisfy all experimental goals. Each flight of roughly $4.5 \mathrm{~h}$ was flown back and forth in a crosswind direction over a single, straight, $72-\mathrm{km}$ horizontal track of relatively uniform land use. Except for coursereversal turns outside the measurement domain, the flight was conducted within a vertical plane, with two exceptions as described below. Figure 4 sketches the standard vertical flight pattern.

During the beginning, middle, and end of this pattern, a vertical sounding and a near-surface leg (solid lines) were flown to estimate the ML depth $z_{i}$, Deardorff velocity $w_{*}$, and buoyancy velocity $w_{B}$. These are ML scaling variables used for all experiment goals. During the two intervals between each pair of scaling legs, a vertical zigzag pattern (dashed lines) was flown in the radix layer. The horizontal length of zig-zag needed for reliable RxL statistics was previously determined using a simulated flight pattern with a synthetic dataset, described by Santoso and Stull (1997b, manuscript submitted to Bound.-Layer Meteor.).

Also during each of the the same two intervals, horizontal legs (long and short dashes) at two altitudes allowed observation of surface layer plumes merging into convective thermals, a process important to formation of BLCu. These legs were parallel to the near-surface ground track but displaced downwind such that the convective flux footprint for that altitude was centered on the near-surface ground track (Weil and Horst 1992). During the second interval, two more horizontal legs were interlaced between the previous two altitudes.

Fair-weather MLs typically have a three-phase growth (Stull 1988): 1) slow growth through the nocturnal stable boundary layer in the early morning, 2) rapid rise through the residual layer in late morning or early afternoon, and 3) deep, nearly steady ML in the afternoon where synoptic-scale subsidence approximately counteracts entrainment. With take-off at noon, our flights occurred during the first half of phase 3 , when both the ML depth and the solar heating were relatively constant.

\section{b. Instrumentation on King Air}

The King Air was configured with the standard University of Wyoming turbulence instrumentation package. Table 1 lists the instruments and their characteristics.

Known errors are summarized here. Preliminary data analysis indicates an erroneous maximum cutoff of $50^{\circ} \mathrm{C}$ for the radiometric skin temperature during flights 1 through 4 (see next section for an index of flights). The data tape from flight 2 was unreadable in the field, but data recovery might be possible. The LI-COR fast-response humidity instrument was inoperative for all of flight 3 . Infrequent intermittent LI-COR outages occurred during flights 1 and 2. The downward-looking solar radiometer had short cutouts during flights 7 and 8 , and was inoperative during all of flight 6 . Thanks to the vigilance of the University of Wyoming program managers during their routine postflight data inspection, these problems were caught early and remedied. The bulk of the data looks reasonable in our preliminary analysis.

\section{c. Collaborators with surface-based sensors}

ANL brought a 915-MHz boundary layer wind profiler (detection altitudes of $100 \mathrm{~m}-4.5 \mathrm{~km}$ ), radio acoustic sounding system (RASS: $100 \mathrm{~m}-2 \mathrm{~km}$ ), and Doppler mini-sodar (10-200 m). It was located at $37.63^{\circ} \mathrm{N}, 96.54^{\circ} \mathrm{W}, 525-\mathrm{m}$ altitude, north of the Winfield flight tracks near the village of Beaumont, Kansas. This site is the first of three remote sensing sites that will compose the permanent ANL boundary layer measurement facility. They plan to compile continuous boundary layer data $24 \mathrm{~h}$ every day during many years. Measurements at this Beaumont site began on 18 July 1996.

NCAR brought their ARM Multiple Antenna Profiler (MAPR), which is part of their integrated sounding system, including a surface weather station, Cross-Chain Loran Atmospheric Sounding System (CLASS) rawinsonde balloon system, and Vaisala ceilometer. Their 915-MHz MAPR wind profiler with RASS was an experimental device that could use either spaced-antenna windfinding or Doppler beam swinging. The site was located at $37^{\circ} 12.1^{\prime} \mathrm{N}, 96^{\circ} 39.77^{\prime} \mathrm{W}, 405-\mathrm{m}$ altitude, near Dexter, Kansas, very close to the Winfield flight track. Their measurements began at roughly 25 July 1996.

As mentioned in the introduction, the ARM CART site was conducting an intensive operation 
TABLE 1. List of standard turbulence-package measurements on the University of Wyoming King Air aircraft.

\begin{tabular}{|c|c|c|c|c|c|}
\hline Parameter & Instrument & Range & Accuracy & Resolution & Sensor mounted \\
\hline Air temperature & Rosemount 102 & $-50^{\circ}$ to $+50^{\circ} \mathrm{C}$ & $0.5^{\circ} \mathrm{C}$ & $0.006^{\circ} \mathrm{C}$ & Left wing tip, below \\
\hline Air temperature & $\begin{array}{l}\text { Reverse flow } \\
\text { (Minco element) }\end{array}$ & $-50^{\circ}$ to $+50^{\circ} \mathrm{C}$ & $0.5^{\circ} \mathrm{C}$ & $0.006^{\circ} \mathrm{C}$ & Right wing tip, below \\
\hline Air temperature & Friehe & $-50^{\circ}$ to $+50^{\circ} \mathrm{C}$ & $0.5^{\circ} \mathrm{C}$ & $0.006^{\circ} \mathrm{C}$ & Nose, below \\
\hline Dewpoint temp. & $\begin{array}{l}\text { Cambridge Sys } \\
\text { Model 137C } 3\end{array}$ & $-50^{\circ}$ to $+50^{\circ} \mathrm{C}$ & $\begin{array}{l}1.0^{\circ} \mathrm{C} \text { for } \mathrm{T}>0^{\circ} \mathrm{C} \\
2.0^{\circ} \mathrm{C} \text { for } \mathrm{T}<0^{\circ} \mathrm{C}\end{array}$ & $0.006^{\circ} \mathrm{C}$ & Body near tail, right \\
\hline Mag. heading & $\begin{array}{l}\text { King KPI } 553 \\
\text { Sperry C14-43 }\end{array}$ & $0^{\circ}-360^{\circ}$ & $1^{\circ}$ & $0.02^{\circ}$ & Nose \\
\hline Static pressure & Rosemount 1501 & $0-108.0 \mathrm{kPa}$ & $0.05 \mathrm{kPa}$ & $0.0003 \mathrm{kPa}$ & $\begin{array}{l}\text { Body near tail, right } \\
\text { and left }\end{array}$ \\
\hline Static pressure & $\begin{array}{l}\text { Rosemount } 1201 \\
\text { FA181A }\end{array}$ & $0-103.4 \mathrm{kPa}$ & $0.05 \mathrm{kPa}$ & $0.006 \mathrm{kPa}$ & $\begin{array}{l}\text { Body near tail, right } \\
\text { and left }\end{array}$ \\
\hline Geometric alt. & $\begin{array}{l}\text { Stewart Warner } \\
\text { APN159 Radar } \\
\text { Alt }\end{array}$ & $0-18288 \mathrm{~m}$ & $1 \%$ & $0.073 \mathrm{~m}$ & $\begin{array}{l}\text { Underneath wing, } \\
\text { near body, right } \\
\text { and left }\end{array}$ \\
\hline Pitot-static diff. & Rosemount 1332 & $0-8.5 \mathrm{kPa}$ & $0.02 \mathrm{kPa}$ & $0.0005 \mathrm{kPa}$ & Nose boom \\
\hline Lat/long & Tremble 2000 GPS & $\begin{array}{c} \pm 90^{\circ} \text { Lat } \\
\pm 180^{\circ} \text { Long }\end{array}$ & $100 \mathrm{~m}$ & $\left(1.72 \times 10^{-4}\right)^{\circ}$ & Cockpit, above \\
\hline Lat/long & $\begin{array}{l}\text { Honeywell } \\
\text { Laseref SM }\end{array}$ & $\begin{array}{c} \pm 90^{\circ} \text { Lat } \\
\pm 180^{\circ} \text { Long }\end{array}$ & $\begin{array}{l}0.8 \mathrm{~mm} \mathrm{~h}^{-1} \text { drift } \\
1.65 \mathrm{~mm} \mathrm{~h}^{-1} \mathrm{drift}\end{array}$ & $\left(1.72 \times 10^{-4}\right)^{\circ}$ & $\begin{array}{l}\text { In middle cabin } \\
\text { (doesn't need } \\
\text { outside sensor) }\end{array}$ \\
\hline
\end{tabular}

period (IOP) from 15 July to 4 August 1996. In fact, this IOP was the reason for conducting our flights at this site and during these weeks. Their observations include an array of surface weather stations, Bowen ratio flux stations, rawinsonde stations with increased launching frequency, radiometric stations, and numerous remote sensors, including radars, wind profilers, RASS, lidars, atmospheric emitted-radiation interferometer spectrometers, and others (Peppler et al. 1996).

\section{Case-study days}

\section{a. Criteria}

Optimal conditions consisted of sunny afternoons, with little or no high and midlevel clouds, and neither thunderstorms nor precipitation. Winds of $0-10 \mathrm{~m} \mathrm{~s}^{-1}$ were acceptable, although light to calm winds were most desired for the CTT goals. We hoped to fly half the flights with no fairweather cumulus clouds, and half with. To forecast BLCu formation and ML growth, a simple one-dimensional ML model based on the thermodynamic method (Stull 1988) was initialized with the early morning rawinsonde sounding from the CART site.

With a total of 60 research flight hours allotted to BLX96, we planned for a total of about 13 flights. The goal was four flights at each location, with half of those flights during clear conditions and half during BLCu cloudy. Because the weather was unusually wet during this field campaign, BLCu were present during most of the flights. 
TABle 1. Continued.

\begin{tabular}{|c|c|c|c|c|c|}
\hline Parameter & Instrument & Range & Accuracy & Resolution & Sensor mounted \\
\hline Ground velocity & $\begin{array}{l}\text { Honeywell } \\
\text { Laseref SM }\end{array}$ & $0-2106 \mathrm{~m} \mathrm{~s}^{-1}$ & $\begin{array}{l}1 \mathrm{~m} \mathrm{~s}^{-1} \text { after } \\
\text { correction }\end{array}$ & $0.0002 \mathrm{~m} \mathrm{~s}^{-1}$ & See above \\
\hline Vertical velocity & $\begin{array}{l}\text { Honeywell } \\
\text { Laseref SM }\end{array}$ & $\pm 166.5 \mathrm{~m} \mathrm{~s}^{-1}$ & $\begin{array}{l}1 \mathrm{~m} \mathrm{~s}^{-1} \text { after } \\
\text { correction }\end{array}$ & $0.00016 \mathrm{~m} \mathrm{~s}^{-1}$ & See above \\
\hline Pitch-roll angle & $\begin{array}{l}\text { Honeywell } \\
\text { Laseref SM }\end{array}$ & $\begin{array}{l} \pm 90^{\circ} \text { pitch } \\
\pm 180^{\circ} \text { roll }\end{array}$ & $0.05^{\circ}$ & $\left(1.72 \times 10^{-4}\right)^{\circ}$ & See above \\
\hline True heading & $\begin{array}{l}\text { Honeyweel } \\
\text { Laseref SM }\end{array}$ & $180^{\circ}$ & $0.2^{\circ}$ & $\left(1.72 \times 10^{-4}\right)^{\circ}$ & See above \\
\hline $\begin{array}{l}\text { Differential } \\
\text { pressure }\end{array}$ & $\begin{array}{l}\text { Rosemount } \\
858 \mathrm{AJ} / 1332\end{array}$ & $\pm 1.5 \mathrm{kPa}$ & $0.02 \mathrm{kPa}$ & $0.000375 \mathrm{kPa}$ & Nose boom \\
\hline Pyranometer & $\begin{array}{l}\text { Eppley PSP } \\
(0.285-2.8 \mu \mathrm{m})\end{array}$ & $0-1400 \mathrm{~W} \mathrm{~m}^{-2}$ & $5 \mathrm{~W} \mathrm{~m}^{-2}$ & $0.08 \mathrm{~W} \mathrm{~m}^{-2}$ & $\begin{array}{l}\text { Middle body, top } \\
\text { and bottom }\end{array}$ \\
\hline Pyrgeometer & $\begin{array}{l}\text { Eppley PIR } \\
(3.5-50 \mu \mathrm{m})\end{array}$ & $0-700 \mathrm{~W} \mathrm{~m}^{-2}$ & $15 \mathrm{~W} \mathrm{~m}^{-2}$ & $0.04 \mathrm{~W} \mathrm{~m}^{-2}$ & $\begin{array}{l}\text { Middle body, top } \\
\text { and bottom }\end{array}$ \\
\hline $\begin{array}{l}\text { Radiation } \\
\text { Pyrometer }\end{array}$ & $\begin{array}{l}\text { Heimann KT-19.85 } \\
(9.6-11.5 \mu \mathrm{m})\end{array}$ & $-50-400^{\circ} \mathrm{C}$ & $0.5^{\circ} \mathrm{C}$ & $0.10^{\circ}$ for $10 \mathrm{~s}$ & Near tail, bottom \\
\hline $\begin{array}{l}\mathrm{H}_{2} \mathrm{O} \\
\text { concentration }\end{array}$ & LI-COR LI 6262 & $0-7.5 \mathrm{kPa}$ & $1 \%$ & $0.01 \mathrm{kPa}$ & $\begin{array}{l}\text { Pipe at top, } \\
\text { middle body }\end{array}$ \\
\hline $\begin{array}{l}\text { Surface and } \\
\text { cloud visual }\end{array}$ & video camera & - & - & - & $\begin{array}{l}\text { Cockpit (forward), } \\
\text { below left engine } \\
\text { (downward) }\end{array}$ \\
\hline
\end{tabular}

\section{b. Flights}

Table 2 shows the research flights during BLX96. The 11th flight on 4 August included only the first half of the pattern (e.g., Fig. 4a, plus a last surface leg and sounding) but was otherwise successful. The 12th flight on 9 August and the 14th flight on 14 August were aborted after the first sounding and near-surface leg due to increasing cloud cover and are considered unsuccessful flights. This leaves 12 successful flights.

\section{Weather}

\section{a. Synoptic and climatic overview}

Table 3 shows climatological conditions in the region of northern Oklahoma, southern Kansas, and northeastern Texas. The region was hot during July and August, with high temperatures frequently near $40^{\circ} \mathrm{C}$. The lee trough on the east side of the Rocky Mountains manifested itself as a dryline from northern Texas through Kansas (Fig. 5a). Typical east-west diurnal oscillation of the dry line spanned the length of the Oklahoma panhandle. The diurnal oscillation was also apparent in the east-west pressure gradient, which strengthened daily and weakened nightly. Thunderstorms commonly occurred near the dryline, but most of the time they were far enough west to remain inconsequential to our study. Cirrus and altocumulus from thunderstorm outflow were often observed to drift over the study area at night.

With the dryline separating air masses, low-level advection of warm, humid air from the gulf of Mexico was unimpeded. Upper-level geopotential fields were relatively flat this time of year, making upper-level winds weak. Winds above $70 \mathrm{kPa}$ gen- 
TABLE 2. Record of flights during BLX96.

\begin{tabular}{|c|c|c|c|c|c|}
\hline Location & $\begin{array}{l}\text { Date } \\
1996\end{array}$ & BLCu & Clear & $\begin{array}{l}\text { Flight } \\
\text { index }\end{array}$ & Hours \\
\hline \multirow[t]{5}{*}{ Lamont } & 21 July & & $X$ & 3 & 4.5 \\
\hline & 23 July & $\mathrm{X}$ & & 5 & 4.4 \\
\hline & 27 July & $X$ & & 7 & 4.4 \\
\hline & $4 \mathrm{Aug}$ & & $X$ & $11 *$ & 3.1 \\
\hline & $13 \mathrm{Aug}$ & & $X$ & 13 & 4.6 \\
\hline \multirow[t]{5}{*}{ Winfield } & 15 July & $X$ & & 1 & 4.4 \\
\hline & 22 July & & $X$ & 4 & 4.5 \\
\hline & 25 July & $X$ & & 6 & 4.5 \\
\hline & 31 July & $X$ & & 9 & 4.5 \\
\hline & $9 \mathrm{Aug}$ & $X$ & & $12 * *$ & 0.8 \\
\hline \multirow[t]{4}{*}{ Meeker } & 16 July & $X$ & & 2 & 4.7 \\
\hline & 28 July & $X$ & & 8 & 4.8 \\
\hline & $2 \mathrm{Aug}$ & & $X$ & 10 & 4.9 \\
\hline & $14 \mathrm{Aug}$ & $X$ & & $14 * *$ & 2.1 \\
\hline
\end{tabular}

*First half of flight pattern only.

**Flight aborted early due to bad weather.

erally flowed from the west or northwest, and the jet stream remained at higher latitudes.

\section{b. Synoptic evolution}

Approximately biweekly, a frontal system disrupted the lee trough and the oscillation of the dry line. By the time the front reached south of the field site, much of its energy was spent, causing it to move slowly through the study area (Fig. 5b). Such was the case during the first week, when the front displayed a north-south diurnal variation, moving farther south during night hours. A weak temperature gradient coupled with a significant dewpoint gradient characterized this front, with dewpoints around $23^{\circ} \mathrm{C}$ south of the front and $19^{\circ} \mathrm{C}$ north.

At the end of the third week and into the fourth, a front characterized by a stronger temperature gradient and weaker dewpoint gradient was present near
TABLE 3. Climatological conditions for the BLX96 region.

\begin{tabular}{lcc}
\hline \multicolumn{1}{c}{ Condition } & July & August \\
\hline Average temperature $\left({ }^{\circ} \mathrm{C}\right)$ & $26.0-28.4$ & $25.1-27.6$ \\
\hline Fraction of possible sunshine $(\%)$ & $73-79$ & $72-79$ \\
\hline Number of clear sky days month ${ }^{-1}$ & $12.0-14.4$ & $13.0-14.9$ \\
\hline Mean wind speeds $\left(\mathrm{m} \mathrm{s}^{-1}\right)$ & $4.0-5.8$ & $3.9-5.6$ \\
\hline Prevailing wind direction & South & South \\
Precipitation $(\mathrm{cm})$ & $6.9-9.2$ & $6.1-7.6$ \\
\hline Tornadoes & $1-2$ & $1-2$ \\
\hline
\end{tabular}

the site that displayed similar behavior. High temperatures were near $38^{\circ} \mathrm{C}$ south and $29^{\circ} \mathrm{C}$ north of the front. Although wind shifts were apparent near the fronts, the low-level winds were generally from the south, both south of the front and farther than $100 \mathrm{~km}$ north of the front. This occurred because the fronts were weak.

As the fronts slowly moved south, dewpoint temperatures in the study area normally dropped for 1 or 2 days. Subsidence contributed to a decrease in the depth of the boundary layer and lapse rates in the early morning lower troposphere were close to moist adiabatic. The stable, drier air and the thinner boundary layer combined to produce mostly clear conditions and virtually no chance of thunderstorms. Though slightly drier, occasionally the post-frontal air was cool enough to form radiation fog over night. Whenever the front was completely out of the region, the flow at lower levels strengthened from the south as the lee trough and dryline reestablished. This brought lapse rates closer to dry adiabatic. The moisture returned and the boundary layer was often deeper, increasing the occurrence of observed cumulus and the chance for thunderstorms.

During the last 2 weeks of the experiment, a deep longwave trough over the eastern half of North America dominated the weather. As shortwaves propagated rapidly along the trough, thunderstorm conditions were optimal. Consequently, the weather was unseasonably poor, as a series of surface fronts passed through the study area with variable speeds and strengths. They displayed simi- 
lar characteristics as those discussed, including stagnation periods near the study area.

Conditions were favorable for flights on those days when a frontal system was not directly over the experiment site. To choose the particular flight location each day, we considered the chance of thunderstorms, morning cloudiness from thunderstorm outflow, fog, and the development of $\mathrm{BLCu}$. We needed morning sunshine to promote boundarylayer development as early as possible in the day and no precipitation or thick mid- and high-level clouds. Since we did not fly close to passing fronts, winds were usually from the south.

Table 4 summarizes the weather conditions for those days that the aircraft flew.

\section{Discussion and conclusions}

A total of 53.3 of the 60 allotted research flight hours were flown during the 12 successful flights. Two other flights (numbers 12 and 14) were aborted, consuming a total of 2.9 flight hours. The last flight (number 14, not listed in some of the previous tables) was unsuccessful, because deteriorating weather prompted us to change locations and then terminate the flight early.

Because of a stalled front that vacillated through the field site, the ML was generally shallower, and the ground moister and cooler, than would have been climatologically expected. The infrequency of anticyclones over the site also reduced the number of flight days experiencing light winds and clear skies.

These conditions affect all three goals. The CTT analysis will be refocused on combined thermal and mechanical turbulence generation. The RxL analysis will be extended from pure free convection to cases of combined (free plus forced) convection. The BLCu study will add cloud shading-induced heterogeneity to factors that affect the JFD.

Detailed data analysis is just beginning. Available now is a technical report (Berg et al. 1997) containing the airborne scientist flight logs. A table of key ML scales, mean meteorological values, and fluxes will be produced in about a year. The raw data is available to outside investigators now, and the calibrated and documented digital data will be made available as soon as it is produced.

Acknowledgments. BLX96 was sponsored by the National Science Foundation (NSF) under Grant ATM-9411467. We appreci- ate the willingness of Greg Tripoli at the University of Wisconsin to serve as U.S. liaison and co-primary investigator for this project.

The experiment would have been impossible without outstanding support from the University of Wyoming (UW) King Air facility, also sponsored by the NSF. We thank pilots Ernie Gasaway and Mark Hoshor, program managers Glenn Gordon and Larry Oolman, and the aircraft support crew Larry Irving and Ken Endsley.

Preliminary research, funded by the Department of Energy (DOE) Grant DE-FG02-92ER61361, led to the definition of goals for the experiment. The continued close cooperation with the ARM Program, also sponsored by the DOE, was greatly appreciated. We give special thanks to ARM researchers and site managers, including Richard Cederwall, Doug Sisterson, and Jim Teske.

Richard Coulter, Tim Martin, Donna Holdridge, and Jerry Klazura of Argonne National Laboratory contributed data from the wind profiler-RASS-sodar site near Beaumont, Kansas. Coulter also coordinated ARM CART 915-MHz wind profiler-RASS measurements near Lamont, Oklahoma. Steve Cohn and Dave Parsons of the National Center for Atmospheric Research, who collaborated with a 915-MHz multiple antenna wind profiler near Dexter, Kansas, were funded by DOE via ARM Grant DE-AI05-90ER61070.

Lawrence Fleck of the Oklahoma State University Extension Center helped identify vegetation and crops from the aerial photographs. We also thank Rich Clark of Millersville University, Pennsylvania, who shared the aircraft to conduct his experiments on the

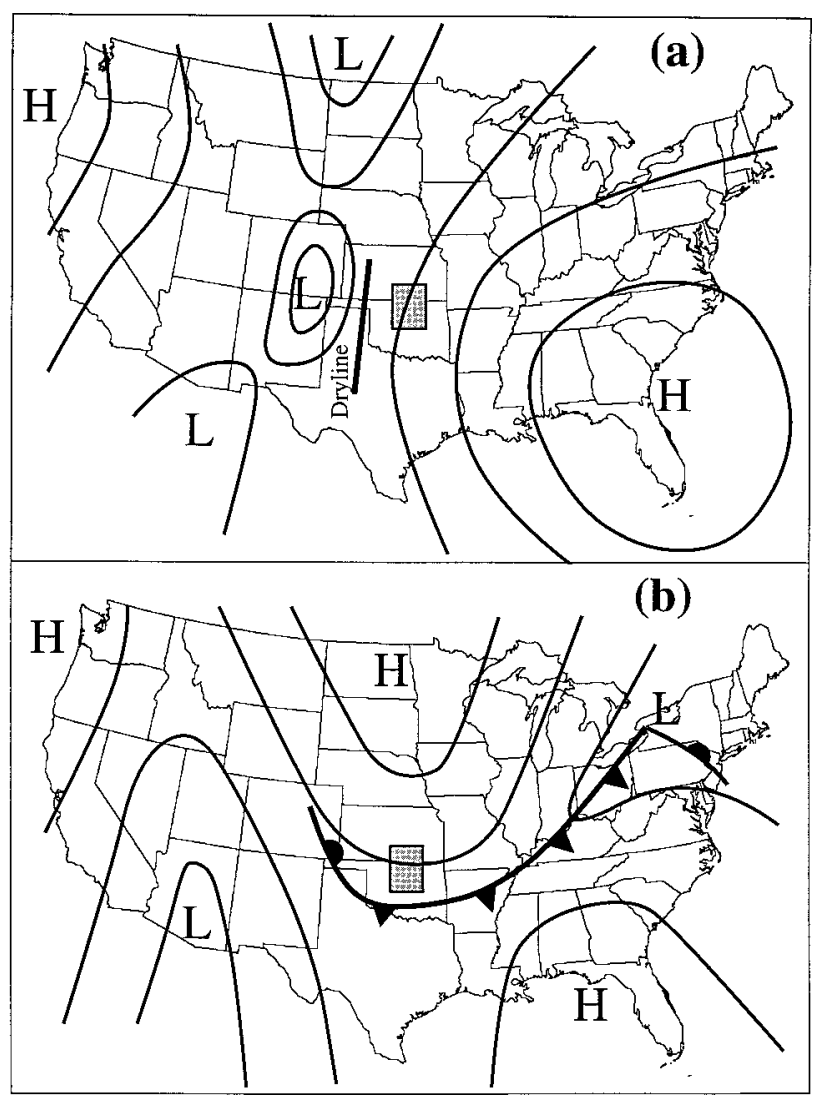

FIG. 5. Sketch of typical synoptic situation, showing idealized isobars (solid lines), fronts and drylines (thick lines), pressure centers, and experiment domain (shaded). (a) Climatologically expected and (b) typically observed during July 1996. 
TABLE 4. Daily weather (wx) conditions during flight days.

\begin{tabular}{|c|c|c|c|}
\hline Date & Wind (Speed, dir.) & Clouds & Comments \\
\hline 15 July & $2.5-5 \mathrm{~m} \mathrm{~s}^{-1}, 180^{\circ}-210^{\circ}$ & $25 \% \mathrm{BLCu}$ & Frontal passage 13 July, little pressure gradient \\
\hline 16 July & $5 \mathrm{~m} \mathrm{~s}^{-1}, 160^{\circ}-180^{\circ}$ & $25 \% \mathrm{BLCu}$ & High to SE blocking approaching low \\
\hline 21 July & Variable southerly & Clear & High to SE prevented widespread CB \\
\hline 22 July & $2.5 \mathrm{~m} \mathrm{~s}^{-1}, 180^{\circ}-200^{\circ}$ & Clear & MCC in Nebraska with approaching front \\
\hline 23 July & Variable southerly & $25 \% \mathrm{BLCu}$ & $\mathrm{CB}$ in north-central $\mathrm{OK}$ previous night with frontal passage \\
\hline 25 July & Variable northerly & $25 \% \mathrm{BLCu}$ & $\begin{array}{l}\text { CB rained heavily on } 24 \text { July, small low-level ridge in region } \\
\text { allowed fair wx }\end{array}$ \\
\hline 27 July & Variable northerly & $15 \% \mathrm{BLCu}$ & $\begin{array}{l}\text { CB rained heavily on } 26 \text { July, small low-level ridge in region } \\
\text { allowed fair wx }\end{array}$ \\
\hline 28 July & Variable southwesterly & $20 \% \mathrm{BLCu}$ & Midlevel ridge gave fair wx over much of the region \\
\hline 31 July & Variable southeasterly & $\begin{array}{l}5 \% \mathrm{BLCu} \\
10 \%-20 \% \mathrm{Ci}\end{array}$ & $\begin{array}{l}\text { Thunderstorms along approaching front kept to } \\
\text { the north during the day }\end{array}$ \\
\hline 2 Aug & Variable southeasterly & Clear & $\begin{array}{l}\text { Front to the south washed out. Mid- and upper-level ridging } \\
\text { kept disturbances to the north }\end{array}$ \\
\hline 4 Aug & $\begin{array}{l}7.5-10 \mathrm{~m} \mathrm{~s}^{-1} \\
160^{\circ}-180^{\circ}\end{array}$ & Clear & $\begin{array}{l}\text { Strong low-level pressure gradient developed } \\
\text { strong winds but kept it clear }\end{array}$ \\
\hline 9 Aug & Variable easterly & Patchy Cc & Flight aborted due to cloud cover \\
\hline 13 Aug & Variable & $\begin{array}{l}\text { Cloudless } \\
\text { and hazy }\end{array}$ & $\begin{array}{l}\text { Ridging at all levels, subsidence kept skies clear; } \\
\text { very moist BL contributed to haze }\end{array}$ \\
\hline 14 Aug & Variable southerly & $>25 \% \mathrm{BLCu}$ & Flight aborted due to cloud cover \\
\hline
\end{tabular}

nocturnal jet. Our cordial interaction with him made administration of the experiment a pleasure.

\section{References}

Berg, L. K., R. B. Stull, E. Santoso, and J. P. Hacker, 1997: Boundary Layer Experiment-1996 (BLX96) airborne scientist flight log. Boundary Layer Research Team Tech. Note BLRT-97-1, 116 pp. [Available from Roland B. Stull, Atmospheric Science Programme, Dept. of Geography, UBC, 1984 West Mall, Vancouver, BC V6T 1Z2, Canada.]

Holtslag, A. A. M., and F. T. M. Nieuwstadt, 1986: Scaling the atmospheric boundary layer. Bound.-Layer Meteor., 36, 201-209.

Panofsky, H. A., 1978: Matching in the convective planetary boundary layer. J. Atmos. Sci., 35, 272-276.

Peppler, R. A., P. J. Lamb, and D. L. Sisterson, 1996: Site scientific mission plan for the southern Great Plains CART site, January-June 1996. Tech. Memo. ARM-96-001, 86 pp. [Available from Office of Scientific and Technical Information, P.O. Box 62, Oak Ridge, TN 37831.]

Santoso, E., 1993: A wind-profile relationship for the unstable surface-layer mixed-layer system. M. S. thesis, Dept. of Atmospheric and Oceanographic Sciences, University of Wisconsin, 59 pp.

Schrieber, K., R. Stull, and Q. Zhang, 1996: Distributions of surface-layer buoyancy versus lifting condensation level over a heterogeneous land surface. J. Atmos. Sci., 53, 1086-1107.

Stull, R. B., 1985: A fairweather cumulus cloud classification scheme for mixed-layer studies. J. Climate Appl. Meteor., 24, 49-56.

__, 1988: An Introduction to Boundary Layer Meteorology. Kluwer, 666 pp.

, 1994: A convective transport theory for surface fluxes. J. Atmos. Sci., 51, 3-22.

Weil, J. C., and T. W. Horst, 1992: Footprint estimates for atmospheric flux measurements in the convective boundary layer. Precipitation Scavenging and Atmosphere-Surface Exchange, Vol. 2, S. E. Schwartz and W. G. N. Slinn, Eds., Hemispheric Publishing, 717-728. 